\title{
Translated language or edited language? A study of passive constructions in translation manuscripts and their published versions
}

\author{
Mario Bisiada \\ Universitat Pompeu Fabra \\ Departament de Traducció i Ciències del Llenguatge \\ C. Roc Boronat, 138, 08018 Barcelona, Spain \\ Tel: +34 935 422244, Email: mario.bisiada@upf.edu
}

Can translated language really be analysed based on published texts, given the many agents that may influence the translator's work before publication? This article seeks to address this question through a parallel corpus study of English business articles, their German translation manuscripts and the published German translations. The objects of study are passive voice constructions. I analyse the frequency of instances where translators used the active voice to translate verbs that are in passive voice in the source text (and vice versa), and whether editors maintained that construction or intervened to change it again. The study finds that translators use the passive voice extensively to translate active voice constructions. Editors intervene often to change such constructions back to active voice. This suggests that translators mainly passivise while editors mainly activise constructions. As a possible motivation to passivise a construction or not, the tense used in the source text is shown to have a significant effect. The paper thus argues that there is a difference between what is actually the language of translation and what we find in published texts.

editing; translation revision; corpus studies; passive voice 


\section{Introduction}

In linguistic studies of translation or translated language, we usually attribute what we observe to translators. We consider translated (written) language to be represented by what we find in published sources such as novels, magazines or newspapers. In this way, we often forget that the language we find in the published product has been influenced by a host of other agents that are involved in the production of a translation. Toury noted that if

it is only pairs of target vs. source texts that are available for study, there is no way of knowing how many different persons were actually involved in the establishment of a translation playing how many different roles. Whatever the number, the common practice has been to collapse all of them into one person and have that conjoined entity regarded as "the translator" (Toury 1995:183).

One of the first to propose the study of those intermediate steps in translation production was Hartmann (1981:206). He proposed "multiphase comparisons", analyses of "successive stages" of "individual attempts" at translations. In particular, he studied changes to a passage of the English translation of Erich Maria Remarque's Im Westen nichts Neues through its various stages from manuscript via proof to the pre-print stage (Hartmann 1980:109, 1981:206).

Similarly, Baker (1993:247) discusses the "question of the intermediate stages of translation, or how the final product evolves over a period of time". She suggests to use corpora to study that evolution, as "access to this type of text in electronic form can be used to explore the process of translation through a retrospective analysis of successive versions of the product" (Baker 1993:247). Most studies, however, draw on published material only, which may yield an incomplete view of translated language because we know nothing about the influence of intermediate agents. I therefore intent to apply the above insights to corpus-based translation studies, and would argue that translated language cannot fully be described by drawing exclusively on published texts.

The influence of editors on literary works has met with some interest recently. Harvey (2003) investigates different ideologies and understandings of the homosexual that compete in the bindings of three 1970s gay fictional texts translated from English to French. He concludes that "inhouse editorial policies make it dangerous to assume that the translator as individual [...] is singly responsible for textual outcomes even in the main body of the text" (Harvey 2003:69). There is an extensive study by Manenti (2010) on the role of editors in shaping the reception of the Journal of Katherine Mansfield, and Eve (2016) analyses content differences through different editorial policies in the US and UK editions of David Mitchell's Cloud Atlas. A range of similar studies aiming to differentiate the voice of the author from that of the editor is presented in Jansen \& Wegener (2013). Studies of literary translation discuss the use of translation drafts in translation criticism (Filippakopoulou 2008). Munday (2013) proposes the use of manuscripts to investigate 
decision-making in translation, arguing that "unpublished primary sources preceding and building to the [target text] itself" are a "valuable window into the working practice of a translator" (Munday 2013:126).

Sinner (2012) studies fictive dialogue in a corpus of 26 romance novels published between 2003 and 2009. The corpus consists of English source texts, their German manuscript translations as well as the published translations (Sinner 2012:136). He notes significant editorial interventions in the translations concerning terms of address and the explicitness of the language. Editors strictly enforce the publishers' guidelines, at times to such an extent that makes style seem more important than correctness. For instance, editors demand that terms of address such as titles be maintained although they might appear unnatural in the German text (Sinner 2012:126). Editors also eliminate swear words and sexual references, even where translators had already toned them down, so that the dialogue, "especially in sex scenes, is far from representing credible orality" (Sinner 2012:133).

Beyond this, studies of the linguistic influence of editors on translated texts, however, are rare. An important study was conducted by Kruger (2012), who investigates differences in the mediation effect between translated and edited language. She finds that "editors introduce collocational variety" whereas translators use "explicit and standardised language" (Kruger 2012:382). McDonough Dolmaya (2015) studies the revision history of 94 translated Wikipedia articles. She finds that content issues such as omissions were "rarely corrected", whereas linguistic issues were eventually resolved, "given enough edits" (McDonough Dolmaya 2015:29). Bisiada (2016:367) finds that sentence splitting is not exclusive to particular translation directions, but also happens in translations from English to German, and editors split sentences almost as frequently as translators.

In a study of English novels translated to Hungarian, Robin (2014) finds that editors perform explicitating and implicitating operations independently of translators. The number of such independent activities "exceeds that of the modifications of transfer operations" (Robin 2014:573), from which she concludes that these phenomena might primarily enter the text at the editorial stage rather than at the translation stage. In a related study of translation universals, Bisiada (forthcoming[b]) has found that the texts only really show a difference in terms of simplification, so that editing in that corpus seems to be "largely a simplifying activity, with editors [...] trying to make the text more comprehensible" (Bisiada forthcoming[b]).

This paper is part of a larger project of editorial intervention in German business articles that seeks to promote greater awareness and inclusion of manuscript corpora in translation studies (Bisiada forthcoming[a]). I have previously reported on an analysis of editorial influence on nominalisations (Bisiada 2017a) and explored possible motivations for this (Bisiada 2017b).

It is the aim of this paper to contribute a study of editorial influence on translated language by comparing the language in a corpus of translation manuscripts with that in a corpus of those same translations in their final, published form. The object of study in this paper is the passive voice, 
more specifically changes made by translators and editors to active and passive sentences in the text they encounter. The role of the passive in translation into German is the focus of Section 2, where I discuss English-German contrasts in this regard (Section 2.1) and the effect of the passive voice on discourse processing issues (Section 2.2). In Section 3, I outline the method and describe the corpus of the study. The main analysis and discussion are presented in Section 4, followed by a conclusion (Section 5).

\section{Passive constructions in German translation}

\subsection{Contrasts between English and German in the voice system}

In the system of voice, German and English clauses both show a contrast between "operative" and "receptive" (Teich 2003:90-96; Halliday \& Matthiessen 2004:182), generally referred to as "active" and "passive". While the contrast does not affect the experiential meaning of the clauses, it changes the mapping of the roles of Actor, Process and Goal "onto the interpersonal functions in the modal structure of the clause" (Halliday \& Matthiessen 2004:182). In English active constructions, the Actor is mapped onto the subject and is thus given modal responsibility as well as being the Theme of the sentence. In passive constructions, on the other hand,

it is the Goal that is mapped on to the Subject, so it is assigned modal responsibility and it is also the Theme in the "unmarked" case; and the Actor has the status of an Adjunct within the Rheme of the clause and, as an Adjunct, it may in fact be left out (Halliday \& Matthiessen 2004:182).

In the case of German, the main function of the voice system is "to make available a potential for varying the mappings of syntactic functions and participant roles" (Teich 2003:90-91). As in English, this variation allows for non-Actors such as the Beneficiary, the Medium or the Range to become the Theme of the sentence (Teich 2003:91; for an explanation of the different participant roles, see Halliday \& Matthiessen 2004:292-296).

There is a contrast between English and German in the participant roles. While in English any kind of participant role can become the subject (Teich 2003:96), German allows only participant roles that have the function of direct object in active voice to become the subject in a passive construction. Constructions with the auxiliary verbs bekommen and kriegen may form exceptions to this rule, but König \& Gast (2012:159) argue that such constructions "belong more to informal, spoken German than to the written language".

The greater flexibility of English in this respect allows for constructions such as the one in example (1) ${ }^{1}$. The sentence is a passive construction with the beneficiary employees as the subject, which would be the indirect object in an active version of this sentence. For the translation to 
German (shown on the left in this and all examples that follow), where only direct objects can be subjects of passive sentences, the translator chose to retain the sentence in passive voice and introduced an empty subject (see Zifonun et al. 1997:1082; Hentschel \& Weydt 2013:322-328). The editor then changed the sentence both grammatically and lexically and turned it into an active construction in the published version (the published translation is shown on the right in all examples in this article).

(1) During their initial training, employees are given the freedom to make judgment calls. (HBR 6/08,96)

In den Einführungskursen wird Mitar- Schon in der Einarbeitungsphase dürbeitern gestattet, nach eigenem Gutdün- fen Mitarbeiter selbstständig entscheiden. ken zu entscheiden. (manuscript) (HBM 9/08,30)

['In the introductory courses, employees ['As early as the initial training, employare permitted to decide at their discre- ees may decide autonomously.'] tion.']

Teich (2003:96) further argues that voice in English fulfills the experiential, textual and interpersonal metafunction to an equal extent, whereas in German it primarily fulfills a textual function. At the same time, German has a greater diversity of Theme options (Teich 2003:119), largely due to freer word order through case markings (Kunz 2010:164), so language users can resort to means other than the passive to control Theme-Rheme organisation.

While the contrasts discussed above may to some extent discourage the use of the passive voice in German translation, there are also some factors that encourage its use. Among them is a semantic restriction of Agents acting as subjects to "animate and conscious participants" (Kunz 2010:166; see also Teich 2003:97), as shown in example (2).

(2) a. To solve such problems, plants have evolved two strategies which they superimpose upon photosynthesis.

b. Zur Lösung solcher Probleme haben sich bei den Pflanzen zwei Mechanismen herausgebildet, von denen die Photosynthese überlagert wird.

['For the solution of this problem, two mechanisms have evolved in plants by which photosynthesis becomes overlaid/superimposed.' $]^{2}$

The above observation is confirmed by examples such as (3), where the source text subject companies is removed and the expression rendered as a passive. Nevertheless, translators seem to accept 
non-animate participants at least with some verbs. In the business genre, personification seems to be acceptable for entities such as board or company. Example (4) from my corpus is very similar to (2), but here the subject is Firmen ('firms') even though it is strictly speaking not animate or conscious. This suggests at least that the differentiation between which Agents may and may not act as subjects in German (and with which verbs) is not always clear.

(3) Having articulated the value proposition for both the customer and the business, companies must then consider the key resources and processes needed to deliver that value. (HBR $12 / 08,50)$

Sobald das Nutzenversprechen sowohl für den Kunden als auch das Unternehmen steht, ist zu überlegen, welche Schlüsselressourcen und -prozesse erforderlich sind, um dieses Nutzenversprechen einzulösen. (manuscript)

['As soon as the value proposition for both the customer and the business stands, it is to be considered which key resources and processes are required to keep that value proposition.']
Sobald das Nutzenversprechen sowohl für den Kunden als auch das Unternehmen definiert ist, sollte überlegt werden, welche Schlüsselressourcen und -prozesse erforderlich sind, um dieses Nutzenversprechen einzulösen. (HBM 4/09,36)

['As soon as the value proposition for both the customer and the business stands, it should be considered which key resources and processes are required to keep that value proposition.']

(4) To get at that, some firms create markets for new customer information in which employees rate the value of contributions. (HBR 1/10,94)

Zur Lösung dieses Problems setzen einige Firmen auf ein System, bei dem die Mitarbeiter die von den Kollegen hinzugefügten Kundeninformationen gegenseitig bewerten. (manuscript)

['For the solution of this problem, some firms put their trust in a system in which employees rate the customer information added by their colleagues.']
Um dieses Problem zu lösen, setzen einige Firmen auf ein System bei dem die Mitarbeiter die von den Kollegen hinzugefügten Kundeninformationen bewerten. (HBM 3/10,86)

['To solve this problem, some firms put their trust in a system in which employees rate the customer information added by their colleagues.'] 
Most style guides for both English and German have traditionally discouraged the use of the passive voice generally (Riggle 1998), though more recent ones are less averted to it (Pinker 2014). Using the passive voice may be preferable in order to achieve the desired Theme-Rheme texture (Halliday \& Matthiessen 2004:232). Biber \& Conrad (2009:122) argue that the general advice of avoiding the passive voice is "misguided". They list several cases in which the passive may be the better choice, for instance where the subject of an active voice construction "would just be a vague group" of agents, so that a passive construction is "more economical and equally instructive" (Biber \& Conrad 2009:123). Using the passive voice allows the object discussed by the sentence to be the subject, allowing readers "to skim quickly and see the main points by looking at the subject of each sentence" (Biber \& Conrad 2009:123), which helps reduce information density.

\subsection{Discourse processing factors of the passive}

We have seen in the previous section that a major function of the passive is to allow the language user to vary the mappings of participant roles in order to allow non-Actors to become the Theme of a sentence. The functional components Theme and Rheme, which serve to structure discourse according to given and new information, are part of the textual metafunction in Systemic Functional Linguistics (Eggins 2004:296; Halliday \& Matthiessen 2004:30), and so the voice system is seen as a textual metafunction (Caffarel et al. 2004:637; Bloor \& Bloor 2013:110). It may then be argued that manipulating the voice system by selecting active or passive constructions metaphorises the text. A passive construction would then be seen as a textual grammatical metaphor.

The notion of textual metaphor is a matter of debate. Its first mention in the literature by Martin (1992:416-417) did not provide a definition, other than that it "construes text as 'material' social reality" by using particular words that "organise text, not field" (Martin 1992:416). He mentions "text reference" devices, such as discourse anaphora, and "internal conjunction", such as for example and let me begin by as examples of such metaphorical realisations. It is not clear from those examples, however, why such constructions are "metaphorical realisations of conjunctive relations" (Martin 1992:416), and so Martin's account remains rather cryptic (for some criticism, see Ravelli 2003:56; see also He 2013:310-311).

Later scholars have proposed various other structures to be cases of textual metaphor. Among them are pseudo-cleft and cleft structures because they need a "double transitivity analysis, one of the original wording and the other of a more congruent rewording" (Thompson 1996:176). Specific adverbial and conjunction groups have also been suggested to count as textual metaphors (He et al. 2015).

A more elaborate account of the passive as metaphor is given by Lassen (2003), who considers passive constructions with an inanimate agent cases of "textural ${ }^{3}$ thematic metaphor". While 
he concedes that sentences with an animate agent may also be considered cases of interpersonal grammatical metaphor (Lassen 2003:42), his main proposition is the notion of "textural metaphor", which refers to incongruent configurations of text organisation, such as the passive voice as well as compound nouns, ellipsis and non-finite clauses (Lassen 2003:43-44; non-finite clauses are also argued to be textual metaphors by He 2013).

The role of the textual function, in his view, is to "generate structuring rules that determine the order of constituents in the clause complex or the order of elements in the group complex" (Lassen 2003:43), so that incongruency is caused by a decreased presence of such structuring rules. In the case of voice, using Halliday's terms (2004:297), an incongruent realisation (that is, a passivisation) would have the Medium as the subject and not as the complement, or an Agent in a role other than the subject (Lassen 2003:46). What makes such expressions metaphorical is "thematic tension caused by the fusion of Agency and Medium/Subject features. In other words, where we might expect to find an Agent (in subject position), we find instead the Medium" (Lassen 2003:46).

Using the passive voice, then, may metaphorise the text if the author creates a texture that exhibits a "marked information focus" (Halliday \& Matthiessen 2004:232). Whether this metaphorisation has an effect on comprehensibility and the ease of processing of the discourse in question is still subject to debate. While the question has been addressed by a sizeable amount of research, no conclusive picture has emerged (for an overview of early research, see Rhodes 1997).

Early psycholinguistic work by Gough $(1965,1966)$ showed that active sentences are indeed processed faster than passive sentences. Adding the factor of negation to the setup, Slobin (1966) found that passive affirmative sentences are processed faster than active negative sentences. According to a study conducted by Tannenbaum \& Williams (1968), the passive voice increased the processing time only in sentences that were focussed on the agent. In a study of the comprehension of legal texts, Charrow \& Charrow (1979) found that passive constructions do not seem to make comprehension more difficult, unless they occur in subordinate clauses. Those studies suggest that voice as a binary variable is not easy to isolate for investigation, as many other features may play a role.

More recent research also finds that passives and negatives increase processing difficulty (Gorin 2005). In an investigation of the effect of specific text properties on reading times, Müller-Feldmeth et al. (2015) had 59 participants read 16 texts and used eye-tracking to measure their eye movements. They find that "[s]entences containing a passive are read longer than sentences without passives" (Müller-Feldmeth et al. 2015:251), but do not enter into a discussion of how reading time and reading difficulty are interrelated. 


\section{Methodology}

\subsection{Resources to express the passive voice in German}

The different passive realisations depend lexico-semantically on whether they express states (Zifonun et al. 1997:1808-1813; Teich 2003:91-92), in which case the verb sein ('to be') is used as shown in example (5), or whether they express processes (Zifonun et al. 1997:1792-1795; Durrell 2003:234), in which case the verb werden ('to become') is used. That is shown in example (6), where the translator turned the active source text verb feed into a passive construction in the target text, which the editor maintained.

(5) For example, when goals are not articulated clearly, work proceeds in wrong directions and performance suffers. (HBR 5/07,72)

Wenn zum Beispiel die Ziele nicht klar formuliert sind, gehen die Anstrengungen nicht in die richtige Richtung. Darunter leidet die Arbeitsleistung. (manuscript)

['When, for example, goals are not articulated clearly, efforts do not go into the right direction. Performance suffers from this.']
Wenn zum Beispiel die Ziele nicht klar formuliert sind, gehen die Anstrengungen nicht in die richtige Richtung. Darunter leidet die Arbeitsleistung. $(9 / 07,48)$

['When, for example, goals are not articulated clearly, efforts do not go into the right direction. Performance suffers from this.']

(6) These perceptions feed the emotions evoked by the event, and the emotions, in turn, feed the perceptions. (HBR 5/07,72)

Diese Wahrnehmungen verstärken die durch das Ereignis ausgelösten Emotionen, und umgekehrt wird durch diese Emotionen auch die Wahrnehmung gestärkt. (manuscript)

['These perceptions strengthen the emotions evoked by the event, and, in turn, the perception is also strengthened by these emotions.']
Diese Wahrnehmungen verstärken die durch das Ereignis ausgelösten Emotionen, und umgekehrt wird durch diese Emotionen auch die Wahrnehmung gestärkt. $(9 / 07,48)$

['These perceptions strengthen the emotions evoked by the event, and, in turn, the perception is also strengthened by these emotions.'] 
The difference between state and event passive is not always clear even for native speakers (Hentschel \& Weydt 2013:117), as the discrepancy between the translated and the edited version in example (7) shows. The translator used the verb sein, thus qualifying the construction as a state passive. The editor changed the verb to werden, so that the construction becomes an event passive.

(7) And many of the events that shape inner work life are caused, directly or indirectly, by managers. (HBR 5/07,72)

Viele der Ereignisse, die diese Gefühls- Viele der Ereignisse, die diese Gefühlsund Gedankenwelt beeinflussen, sind di- und Gedankenwelt beeinflussen, werden rekt oder indirekt von Managern verur- direkt oder indirekt von Managern verursacht. (manuscript) sacht. (HBM 9/07,48)

['Many of the events that shape this world ['Many of the events that shape this world of feelings and thoughts were directly or indirectly caused by managers.']

of feelings and thoughts are directly or indirectly caused by managers.']

Passives can also be classified according to the involvement of modality (Teich 2003:92; König \& Gast 2012:161). In such passive constructions, the verb sein ('to be') is used with a modal infinitive phrase, which achieves a type of modality that is "ambiguous between possibility and obligation" (Teich 2003:92). Example (3) above shows such a case of ambiguity. The translator has used the modal infinitive to translate the verb must. The editor, perhaps dissatisfied with the ambiguity, changed the construction to a proper passive and added the auxiliary sollte ('should') to clarify the modality.

Another commonly used passive has been termed "bene-receptive passive" (Teich 2003:92; Eisenberg et al. 2013:133; Hentschel \& Weydt 2013:120) or "bekommen passive" (Helbig \& Buscha 2011:167; Zifonun et al. 1997:1824), because it is formed with bekommen, kriegen or erhalten ('to get', 'to receive'; see example (8)). This form has long been used in spoken German and has recently grammaticalised (Askedal 2005:221). Some evidence suggests that it may also to an increasing extent be found in written German (Denter 2013:62).

(8) “My eight-year-old just asked me what a 'stairway to heaven' is," Veronica was saying, "and wants to know if Santa will bring her one for Christmas." (HBR 12/09,33) 
"Meine elfjährige Tochter hat mich gefragt, was 'Stairway to heaven' bedeutet", erzählte Veronica, "und dann hat sie mich gefragt, ob sie so eine Treppe in den Himmel zu Weihnachten geschenkt bekommt". (manuscript)

["'My eleven-year-old daughter asked me what 'stairway to heaven' means", said Veronica, "and then she asked me if she will be given such a stairway to heaven for Christmas."']
"Meine elfjährige Tochter hat mich gefragt, was 'Stairway to heaven' bedeutet", erzählte Veronica, "und dann hat sie mich gefragt, ob sie so eine Treppe in den Himmel zu Weihnachten geschenkt bekommt". (HBM 1/10,82)

["My eleven-year-old daughter asked me what 'stairway to heaven' means", said Veronica, "and then she asked me if she will be given such a stairway to heaven for Christmas."']

In addition to those "true" passives, there are some alternatives that achieve a similar function. These passive alternatives are used increasingly frequently in professional and scientific discourse by authors who seek to avoid using the passive voice but still want to keep the language economical (see Gang 1997). These alternatives are the impersonal construction man ('one') (Zifonun et al. 1997:1838; Hentschel \& Weydt 2013:237; Gast 2015) and the modal passive, which features a combination of lassen ('to let') and a reflexive verb (König \& Gast 2012:162; Zifonun et al. 1997:1792; Hentschel \& Weydt 2013:123), as shown in example (9). That construction achieves the same effect as the passive without "chang[ing] the morphological properties of the underlying predicate" (Steinbach 2002:1). Passive alternatives will not be analysed here because I have analysed these important items in Bisiada (forthcoming $[b]$ ).

(9) Customer equity has the added benefit of being a good proxy for the value of the firm, thereby making marketing more relevant to shareholder value. (HBR 1/10,94) 
Die Betrachtung des Werts der Kunden hat einen weiteren Vorteil, denn an ihm lässt sich gut der Wert des Unternehmens ablesen. Insofern gewinnt das Marketing auch für den Shareholder-Value an Bedeutung. (manuscript)

['Considering customer equity has another benefit because the value of the company can be read from it. Thus, marketing also becomes more relevant to shareholder value.']
Wer den Wert der Kunden betrachtet, erhält auch Informationen über den Wert des Unternehmens. Insofern gewinnt das Marketing auch für den ShareholderValue an Bedeutung. (HBM 3/10,86)

['He who considers the value of the client also receives information about the value of the company. Thus, marketing also becomes more relevant to shareholder value.']

\subsection{Corpus and procedure}

This study draws on a tripartite parallel corpus "in which two or more components are aligned, that is, are subdivided into compositional and sequential units (of differing extent and nature) which are linked and can thus be retrieved as [...] triplets" (Fantinuoli \& Zanettin 2015:4). A translation corpus of English source texts and their German translations is complemented by a corpus of the manuscripts of those translations (see Table 1). All texts date from 2006 to 2011. The manuscripts were sent to the publisher by the translation company Rheinschrift ${ }^{4}$ and thus represent translated language before editors worked on it. The texts were translated by 7 different translators, according to the translation agency, and then edited by 3 different in-house editors, according to the editor-inchief at the Harvard Business Manager. As these were the only manuscripts available, the corpora could not be bigger in size, but due to the large amount of editorial changes effected I believe that they still provide a meaningful picture of the editorial activity at this magazine.

Table 1: Size of the corpus in words

\begin{tabular}{ll}
\hline English source texts & 104,678 \\
German manuscript translations & 106,829 \\
German published translations & 104,448 \\
\hline Total size & 315,955 \\
\hline
\end{tabular}

The analysis conducted here consists of two steps. First, the two German subcorpora are each analysed for passive constructions, through a search for the lemmas werden and sein and a manual analysis to filter out non-passive constructions. The corresponding construction in the respective 
other subcorpus is then noted. This method observes discrepancies between manuscript and published translations. Where the content that is expressed as a passive in one of the corpora is omitted in one of the other corpora, the triplet was excluded from the analysis.

In the second step, the subcorpus of English texts is analysed for English passives in order to also discover cases where such passive constructions were turned into active constructions by the translator and maintained as such by the editor. The English passive constructions were found by searching for participles and the lemma be in the vicinity before it. This two-step procedure will yield results as to translators' and editors' treatment of passive forms at the respective steps in the translation production.

\section{Analysis of metaphorisation patterns}

In roughly a quarter of cases containing a passive construction in this corpus, the use of the passive voice has not been affected by either translator or editor, a pattern I refer to as "PPP". The most common metaphorisation pattern is that a translator renders an active verb in the source text using the passive voice in the target text and the editor maintains this choice (“APP”). This pattern is shown in examples (6), (3) and (8) above. A related pattern, where the source text has a noun that translators have turned into a passive verb and which the editor has kept ("NPP”), as in example (10), can also be observed commonly.

(10) Consider the following example, in which a client had requested a software development project with a firm deadline. (HBR 5/07,72)

$\begin{array}{ll}\begin{array}{l}\text { Im folgenden Beispiel musste für einen } \\ \text { Kunden innerhalb eines unumstößlichen }\end{array} & \begin{array}{l}\text { Im folgenden Beispiel musste für einen } \\ \text { Kunden innerhalb eines unumstößlichen }\end{array} \\ \begin{array}{l}\text { Zeitrahmens eine Software entwickelt } \\ \text { werden. (manuscript) }\end{array} & \begin{array}{l}\text { Zeitrahmens eine Software entwickelt } \\ \text { werden. (HBM 9/07,48) }\end{array} \\ \begin{array}{ll}\text { ['In the following example, a piece of } & \text { ['In the following example, a piece of } \\ \text { software had to be developed for a client } & \text { software had to be developed for a client } \\ \text { within a firm deadline.'] } & \text { within a firm deadline.'] }\end{array}\end{array}$

While editors often maintain the translators' passive rendering of an active verb in the source text, they do not by any means always do so. More than one in three times, they intervene by changing the passive construction in the manuscript back to an active construction, reflecting the source text (“APA”, see example 11). 
(11) In an Office, people generally deem a space to be a comfortable, natural place to interact only if company culture, reinforced by management, designates it as such. (HBR 7/11,102)

In einem Büro werden Räumlichkeiten nur dann als geeigneter Ort für Kontakte betrachtet, wenn sie durch die vom Management bestärkte Unternehmenskultur als solche ausgewiesen sind. (manuscript)

['In an office, spaces are only deemed as an appropriate place for contacts if they are designated as such by the company culture, reinforced by management.']
Mitarbeiter betrachten Räume nur dann als angenehme und geeignete Orte für Begegnungen, wenn die von den Managern gelebte Unternehmenskultur sie als solche ausweist. (HBM 10/11,46)

['Staff only deem rooms as pleasant and appropriate places for encounters if the company culture, lived by management, designates them as such.']

As stated above, where the source text has a passive construction and the translator also used a passive voice, editors do not intervene in the majority of cases. However, in one in six cases, editors activise those constructions ("PPA"), which can be seen in example (1) above. There are also cases where editors have passivised a construction where the translator maintained the active voice from the source text (“AAP”), as in example (12).

(12) They give narrowly defined objectives to some but not all units and don't put enough thought into how the individual units' strategies will support the overarching strategy of the business. (HBR 9/09,90)

Sie legen genau formulierte Ziele für einige Unternehmenseinheiten fest, machen sich aber nicht genügend Gedanken darüber, wie die Strategie der einzelnen Einheiten in die Gesamtstrategie des Unternehmens eingebunden ist. (manuscript)

['They set precisely defined targets for some company units, but don't think enough about the strategy of the individual units is involved in the overarching strategy of the business.']
Für einige ausgewählte Unternehmenseinheiten werden präzise formulierte Ziele festgelegt, ohne dass das Management jedoch ausreichend darüber nachdenkt, wie sich die Strategie dieser Einheiten zur Gesamtstrategie des Unternehmens verhält. (HBM 12/09,78)

['For some selected company units, precisely defined targets are set without the management thinking sufficiently about how the strategy of these units is related to the overarching strategy of the business.'] 
Activisations on the part of the translator ("PAA"), as in example (13), are not as common as passivisations.

(13) The notion arose from the experienced gamers on our research team, who were puzzled by our initial preoccupation with the individual qualities of game leaders. (HBR 5/08,58)

Die Vorstellung geht auf die erfahrenen Die Idee dazu kam vielmehr von erfahRollenspieler zurück, die sich über unsere renen Rollenspielern, die sich über unseanfängliche Fixierung auf die individuel- re Fixierung auf die individuellen Eigenlen Eigenschaften der Anführer im Spiel schaften der Anführer im Spiel wunderwunderten. (manuscript) ten. (HBM 6/08,76)

['The view goes back to the experienced role play gamers who were wondering at our initial fixation on the individual qualities of game leaders.']

['Rather, the idea for this came from experienced role play gamers, who were wondering at our fixation on individual qualities of game leaders in the game.']

The overall results of the analysis are presented in Table 2. Translators have turned 489 constructions that were active in the source text into passive voice (APP and APA), but only 99 passive constructions into active (PAA and PAP) or nominal (PNN and PNP) constructions. This may show that, despite the criticism that has been levelled at it by scholars of text production (see Section 2.2), the passive voice is still frequently used in German translations, at least in this genre.

Editors, though, seem to be less in favour of passive constructions, which would be explained by reference to the house style of the Harvard Business Manager that tells authors to "avoid the passive voice". More than a third of translators' passivisations of active constructions have been re-activised by editors (189 out of 489 instances), and editors activise almost as many forms (47 instances) as translators (57 instances). They turn fewer constructions into passive (34 passivisations by editors as opposed to 549 by translators), and re-passivisations ("PAP" and "PNP") are also rare (7 instances together).

There seem to be differences, then, in the principles guiding the linguistic activities of translating and editing, which argue that, while both translating and editing may be considered forms of mediated discourse as proposed by Ulrych \& Murphy (2008:150), they do seem to be fundamentally different linguistic activities. In the present case, there may be a difference between faithfulness to the source text, which may prompt translators to maintain the passive voice, and considerations of readability, leading editors to change the manuscript and remove some passive voice constructions.

To elicit possible motivations that inform editors' and translators' decisions to passivise or activise, I have analysed the tense of the constructions in order to find out if editors and translators 
Table 2: Metaphorisation patterns: Source text forms and actions taken by translators and editors

\begin{tabular}{|c|c|c|c|c|}
\hline Abbr. & ST form & Translator's action & Editor's action & Instances \\
\hline APP & active & passivisation & - & 300 \\
\hline APA & active & passivisation & re-activisation & 189 \\
\hline AAP & active & - & passivisation & 34 \\
\hline PAA & passive & activisation & - & 56 \\
\hline PAP & passive & activisation & re-passivisation & 1 \\
\hline PPA & passive & - & activisation & 47 \\
\hline NPP & nominal & passivisation & - & 51 \\
\hline NPN & nominal & passivisation & re-nominalisation & 9 \\
\hline NNP & nominal & - & passivisation & 5 \\
\hline PNN & passive & nominalisation & - & 36 \\
\hline PNP & passive & nominalisation & re-passivisation & 6 \\
\hline PPN & passive & - & nominalisation & 6 \\
\hline PPP & passive & - & - & 250 \\
\hline Total & & & & 990 \\
\hline
\end{tabular}

are more likely to passivise or activise depending on whether the construction is in present or past tense. The result is shown in Table 3. Statistical significance has been ascertained by calculating the significance of the difference between the two independent proportions, expressed by a $z$-ratio, which has a two-tailed probability associated with it (Cantos Gómez 2013:83). The alpha level of statistical significance chosen here is 0.01 .

Table 3: Passivisations and activisations separated by present and past tense

\begin{tabular}{lrrrr}
\hline & \multicolumn{2}{c}{ Translators } & \multicolumn{2}{c}{ Editors } \\
& Passivisation & Activisation & Passivisation & Activisation \\
\hline Present & $51 \%$ & $3 \%$ & $4 \%$ & $24 \%$ \\
Past & $36 \%$ & $11 \%$ & $3 \%$ & $23 \%$ \\
\hline$z$-ratio & 4.575 & -4.883 & 0.428 & 0.544 \\
$p$-value & $<.0002$ & $<.0002$ & 0.6687 & 0.5864 \\
\hline
\end{tabular}

As noted above, editors engage more in activisation than in passivisation. Their decision as to which constructions to activise or passivise, however, does not seem to depend on whether the construction is in present or past tense. For translators, on the other hand, that distinction does seem to play a role. There are significantly more passivised constructions that are in present tense than in past tense $(z=4.575, p<0.01)$. Thus, translators seem to be more likely to render an active construction in the source text as a passive construction if the construction is in present tense. At 
the same time, when translators do translate passive constructions as active ones, they tend to activise those in past tense significantly more frequently than those in present tense $(z=-4.883$, $p<0.01)$.

What makes a language user decide to use passive or active voice has not been studied to a significant extent, simply because it is hard to elicit by empirical methods. From the present findings, it seems that the passive voice is more acceptable to German translators in this genre in present tense expressions. This may just be coincidental, or there may be some motivations behind it. There seem to be factors that translators consider beyond the faithfulness to the source text, although the precise reasons for this phenomenon are unclear and demand further quantitative and qualitative research into translator decision-making with reference to the voice system of their language. Future studies drawing on corpora tagged for animate and conscious subjects, for instance, might test the contrasts discussed in Section 2.1 to find out, for instance, whether animate and conscious participants as subjects trigger the use of the passive voice.

\section{Conclusion}

In this paper, I have analysed the treatment of passive constructions by translators and editors in the translation production process. To this effect, I have compared manuscripts and published versions of German translations of English business articles. I have found that translators render a large amount of active constructions as passive constructions in their translations, making such passivisations more common in translated language than the reverse phenomenon, activisation. Editors, on the other hand, intervene in more than one third of cases to change the constructions back into active voice. They also activise constructions that the translators left in the passive voice. Thus, editing is marked more by activisation than passivisation.

A qualitative follow-up analysis has revealed that the tense of the verb plays a role, in that translators are more likely to accept passive sentences when they are in the present tense. Past tense verbs are less likely to be passivised when they are in the active voice in the source text, and are activised more often when the source text has them in passive voice.

This paper has sought to promote a differentiated view of the translation (production) process by shedding light on what happens to a document between translation and publication. The benefit of this type of research for corpus-based translation studies is that it shows the actual language of translation, i.e. before it undergoes the influence of editors. That language has been shown to differ significantly, at least with respect to passive use, from what we find in published texts. The degree of passive use that we observe in actual translated language is significantly higher than that which we would observe in published translations. Thus, ignoring the influence of editors on the text may provide us with a heavily distorted picture of translated language. 


\section{Notes}

\footnotetext{
${ }^{1}$ All English source text sentences are taken from the Harvard Business Review ("HBR"). The German translations shown are the manuscript translation on the left and the edited translation as published in the Harvard Business Manager ("HBM") on the right. For more information on the corpora, see Section 3.2

${ }^{2}$ Translation taken from Steiner (2004:145).

${ }^{3}$ Lassen uses the term "textural metaphor", "due to its origin in texture" (2003:31).

${ }^{4}$ I would like to thank my friend Ralph Krüger for liaising with the company so that I could obtain this valuable data.
}

\section{References}

Askedal, J. O. 2005. Grammatikalisierung und Persistenz im deutschen "Rezipienten-Passiv" mit bekommen / kriegen / erhalten. In: Leuschner, T., Mortelmans, T. \& Groodt, S. D. (eds.) Grammatikalisierung im Deutschen. Berlin: de Gruyter. 211-228.

Baker, M. 1993. Corpus Linguistics and Translation Studies: Implications and Applications. In: Baker, M., Francis, G. \& Tognini-Bonelli, E. (eds.) Text and Technology: In Honour of John Sinclair. Amsterdam: John Benjamins. 233-250.

Biber, D. \& Conrad, S. 2009. Register, Genre, and Style. Cambridge: Cambridge University Press.

Bisiada, M. Forthcoming(a). The Editor's Invisibility: Analysing Editorial Intervention in Translation. Target.

Bisiada, M. Forthcoming(b). Universals of Editing and Translation. In: Hansen-Schirra, S., Hofmann, S. \& Meyer, B. (eds.) Empirically Modelling Translation and Interpreting. Berlin: Language Science Press.

Bisiada, M. 2016. "Lösen Sie Schachtelsätze möglichst auf”: The Impact of Editorial Guidelines on Sentence Splitting in German Business Article Translations. Applied Linguistics Vol. 37. No. (3). 354-376.

Bisiada, M. 2017a. Editing Nominalisations in English-German Translation: When do Editors Intervene? The Translator Vol. Advance online access. No.

Bisiada, M. 2017b. Translation and Editing: A Study of Editorial Treatment of Nominalisations in Draft Translations. Perspectives Vol. Advance online access. No.

Bloor, T. \& Bloor, M. 2013. The Functional Analysis of English. 3rd edn. Abingdon: Routledge.

Caffarel, A., Martin, J. R. \& Matthiessen, C. M. I. M. 2004. Language Typology: A Functional Perspective. Amsterdam: John Benjamins.

Cantos Gómez, P. 2013. Statistical Methods in Language and Linguistic Research. Sheffield: Equinox. 
Charrow, R. P. \& Charrow, V. R. 1979. Making Legal Language Understandable: A Psycholinguistic Study of Jury Instructions. Columbia Law Review Vol. 79. No. (7). 1306-1374.

Denter, T. 2013. Das deutsche Rezipientenpassiv im Kontext medialer und konzeptioneller Mündlichkeit und Schriftlichkeit. Essen: LINSE.

Durrell, M. 2003. Using German: A Guide to Contemporary Usage. 2nd edn. Cambridge: Cambridge University Press.

Eggins, S. 2004. An Introduction to Systemic Functional Linguistics. 2nd. London: Bloomsbury.

Eisenberg, P., Fuhrhop, N. \& Thieroff, R. 2013. Grundriss der deutschen Grammatik. Vol. 2: Der Satz. 4th edn. Stuttgart: Metzler.

Eve, M. P. 2016. "You Have to Keep Track of Your Changes": The Version Variants and Publishing History of David Mitchell's Cloud Atlas. Open Library of Humanities Vol. 2. No. (2). e1.

Fantinuoli, C. \& Zanettin, F. 2015. Creating and Using Multilingual Corpora in Translation Studies. In: Fantinuoli, C. \& Zanettin, F. (eds.) New Directions in Corpus-Based Translation Studies. Berlin: Language Science Press. 1-10.

Filippakopoulou, M. 2008. Translation Drafts and the Translating Self. In: Nikolaou, P. \& Kyritsi, M.-V. (eds.) Translating Selves: Experience and Identity between Languages and Literatures. London: Continuum. 19-36.

Gang, G.-J. 1997. Passivsynonyme als Elemente der wissenschaftlichen Fachsprache im Deutschen. Frankfurt/M.: Peter Lang.

Gast, V. 2015. On the Use of Translation Corpora in Contrastive Linguistics: A Case Study of Impersonalisation in English and German. Languages in Contrast Vol. 15. No. (1). 4-33.

Gorin, J. S. 2005. Manipulating Processing Difficulty of Reading Comprehension Questions: The Feasibility of Verbal Item Generation. Journal of Educational Measurement Vol. 42. No. (4). $351-373$.

Gough, P. P. 1965. Grammatical Transformations and Speed of Understanding. Journal of Verbal Learning and Verbal Behavior Vol. 4. No. (2). 107-111.

Gough, P. P. 1966. The Verification of Sentences: The Effects of Delay of Evidence and Sentence Length. Journal of Verbal Learning and Verbal Behavior Vol. 5. No. (5). 492-496.

Halliday, M. A. K. \& Matthiessen, C. M. I. M. 2004. An Introduction to Functional Grammar. 3rd edn. London: Arnold.

Hartmann, R. R. K. 1980. Contrastive Textology: Comparative Discourse Analysis in Applied Linguistics. Heidelberg: Julius Groos.

Hartmann, R. R. K. 1981. Contrastive Textology and Translation. In: Kühlwein, W., Thome, G. \& Wilss, W. (eds.) Kontrastive Linguistik und Übersetzungswissenschaft. München: Fink. 200208. 
Harvey, K. 2003. "Events" and "Horizons": Reading Ideology in the "Bindings" of Translations. In: Pérez, M. C. (ed.) Apropos of Ideology. Manchester: St Jerome. 43-69.

He, Q. 2013. Textual Metaphor from the Non-Finite Clausal Perspective. Open Journal of Modern Linguistics Vol. 3. No. (4). 308-313.

He, Q., Yang, B. \& Wen, B. 2015. Textual Metaphor from the Perspective of Relator. Australian Journal of Linguistics Vol. 35. No. (4). 334-350.

Helbig, G. \& Buscha, J. 2011. Deutsche Grammatik: Ein Handbuch für den Ausländerunterricht. Berlin: Langenscheidt.

Hentschel, E. \& Weydt, H. 2013. Handbuch der deutschen Grammatik. 4th edn. Berlin: de Gruyter. Jansen, H. \& Wegener, A. (eds.). 2013. Authorial and Editorial Voices in Translation. Vol. 2 Editorial and Publishing. Montreal: Editions Québécoises de L'Oeuvre.

König, E. \& Gast, V. 2012. Understanding English-German Contrasts. 3rd edn. Berlin: Erich Schmidt Verlag.

Kruger, H. 2012. A Corpus-Based Study of the Mediation Effect in Translated and Edited Language. Target Vol. 24. No. (2). 355-388.

Kunz, K. A. 2010. Variation in English and German Nominal Coreference: A Study of Political Essays. Frankfurt/M.: Peter Lang.

Lassen, I. 2003. Accessibility and Acceptability in Technical Manuals: A Survey of Style and Grammatical Metaphor. Amsterdam: John Benjamins.

Manenti, D. 2010. Inside the Black Box: Notes around the Editorial Manipulation of the Journal of Katherine Mansfield. La Libellula Vol. 2. No. 172-178.

Martin, J. R. 1992. English Text: System and Structure. Amsterdam: John Benjamins.

McDonough Dolmaya, J. 2015. Revision History: Translation Trends in Wikipedia. Translation Studies Vol. 8. No. (1). 16-34.

Müller-Feldmeth, D., Held, U., Auer, P., Hansen-Morath, S., Hansen-Schirra, S., Maksymski, K., Wolfer, S. \& Konieczny, L. 2015. Investigating Comprehensibility of German Popular Science Writing. In: Maksymski, K., Gutermuth, S. \& Hansen-Schirra, S. (eds.) Translation and Comprehensibility. Berlin: Frank \& Timme. 227-261.

Munday, J. 2013. The Role of Archival and Manuscript Research in the Investigation of Translator Decision-Making. Target Vol. 25. No. 125-139.

Pinker, S. 2014. The Sense of Style: The Thinking Person's Guide to Writing in the 21st century. New York: Penguin.

Ravelli, L. J. 2003. Renewal of Connection: Integrating Theory and Practice in an Understanding of Grammatical Metaphor. In: Vandenbergen, A.-M., Taverniers, M. \& Ravelli, L. J. (eds.) Grammatical Metaphor: Views from Systemic Functional Linguistics. Amsterdam: John Benjamins. 37-64. 
Rhodes, S. 1997. The Active and Passive Voice are Equally Comprehensible in Scientific Writing. University of Washington PhD thesis.

Riggle, K. B. 1998. Using the Active and Passive Voice Appropriately in On-the-Job Writing. Journal of Technical Writing and Communication Vol. 28. No. (1). 85-117.

Robin, E. 2014. Explicitation and Implicitation in Revised Translations. In: Veselovská, L. \& Janebová, M. (eds.) Complex Visibles Out There: Proceedings of the Olomouc Linguistics Colloquium 2014: Language Use and Linguistic Structure. Olomouc: Palacký University. 559_ 574.

Sinner, C. 2012. Fictional Orality in Romance Novels: Between Linguistic Reality and Editorial Requirements. In: Brumme, J. \& Espunya, A. (eds.) The Translation of Fictive Dialogue. Amsterdam: Rodopi. 119-136.

Slobin, D. I. 1966. Grammatical Transformations and Sentence Comprehension in Childhood and Adulthood. Journal of Verbal Learning and Verbal Behavior Vol. 5. No. (3). 219-227.

Steinbach, M. 2002. Middle Voice: A Comparative Study in the Syntax-Semantics Interface of German. Amsterdam: John Benjamins.

Steiner, E. 2004. Ideational Grammatical Metaphor: Exploring some Implications for the Overall Model. Languages in Contrast Vol. 4. No. (1). 137-164.

Tannenbaum, P. H. \& Williams, F. 1968. Generation of Active and Passive Sentences as a Function of Subject or Object Focus. Journal of Verbal Learning and Verbal Behavior Vol. 7. No. (1). 246-250.

Teich, E. 2003. Cross-Linguistic Variation in System and Text. Berlin: de Gruyter.

Thompson, G. 1996. Introducing Functional Grammar. London: Arnold.

Toury, G. 1995. Descriptive Translation Studies and Beyond. Amsterdam: John Benjamins.

Ulrych, M. \& Murphy, A. 2008. Descriptive Translation Studies and the Use of Corpora: Investigating Mediation Universals. In: Torsello, C. T., Ackerley, K. \& Castello, E. (eds.) Corpora for University Language Teachers. Frankfurt/M.: Peter Lang. 141-166.

Zifonun, G., Hoffmann, L. \& Strecker, B. 1997. Grammatik der deutschen Sprache. Berlin: de Gruyter. 